\title{
ANALISIS PENGARUH ASEAN CORPORATE GOVERNANCE SCORECARD, LEVERAGE, SIZE, GROWTH OPPORTUNITIES, DAN EARNINGS PRESSURE TERHADAP KONSERVATISME AKUNTANSI (Studi Kasus Pada Perusahaan Top Rank 50 ASEAN Corporate Governance Scorecard Di Indonesia yang terdaftar di Bursa Efek Indonesia Pada tahun 2013-2015)
}

\begin{tabular}{|c|c|}
\hline \multicolumn{2}{|c|}{$\begin{array}{l}\text { Aes Sulastri, Sri Mulyati, Icih } \\
\text { STIE Sutaatmadja (STIESA) Subang }\end{array}$} \\
\hline INFO ARTIKEL & ABSTRAK/ABSTRACK \\
\hline $\begin{array}{l}\text { Histori Artikel : } \\
\text { Tgl Masuk : } 31 \text { Okt. } 2017 \\
\text { Tgl Diterima : } 10 \text { Feb. } 2018 \\
\text { Tersedia Online : } 5 \text { Maret } 2018 \\
\text { Keywords: }\end{array}$ & $\begin{array}{l}\text { The purpose of this research is to determine the effect of } \\
\text { ASEAN corporate governance scorecard, leverage, size, } \\
\text { growth opportunities, and earnings pressure to accounting } \\
\text { conservatism on Top Ranking } 50 \text { Companies ASEAN Corporate } \\
\text { Governance Scorecard. }\end{array}$ \\
\hline $\begin{array}{l}\text { ASEAN Corporate Governance } \\
\text { Scorecard, Leverage, size, growth } \\
\text { opportunities, earnings pressure, } \\
\text { Konservatisme Akuntansi, } \\
\text { Accounting Conservatism }\end{array}$ & $\begin{array}{l}\text { The population used in this research is Top Ranking } 50 \\
\text { Companies ASEAN Corporate Governance Scorecard based on } \\
\text { the assessments by Indonesian Institute for Corporate } \\
\text { Directorship (IICD) listed in Indonesia Stock Exchange (BEI). } \\
\text { The technique of sample selection used purposive sampling. } \\
\text { Based on these criteria, obtained samples as much as } 49 \\
\text { companies during the observation period 2013-2015. The } \\
\text { analytical tool used in this study is the panel regression and } \\
\text { hypothesis testing using t-test, f-test and the coefficient } \\
\text { determination by used the program Eviews } 9 \text {. }\end{array}$ \\
\hline & $\begin{array}{l}\text { These results indicate that the ASEAN Corporate Governance } \\
\text { Scorecard have a significant negative effect on accounting } \\
\text { conservatism. Leverage, size, and growth opportinities have a } \\
\text { significant positive effect on accounting conservatism, but } \\
\text { earnings pressure has no significant effect on accounting } \\
\text { conservatism. }\end{array}$ \\
\hline
\end{tabular}

\section{PENDAHULUAN}

Laporan keuangan merupakan suatu bentuk pertanggungjawaban manajemen dalam mengelola sumber daya perusahaan. Informasi yang disampaikan dalam laporan keuangan digunakan sebagai dasar pengambilan keputusan bagi pihak internal. Agar dapat dipertanggungjawabkan isinya serta bermanfaat bagi penggunanya, laporan keuangan harus memiliki tujuan, aturan, serta prinsip-prinsip akuntansi yang sesuai dengan standar yang berlaku (Deviyanti, 2012). Standar Akuntansi Keuangan memberikan kebebasan bagi perusahan untuk memilih metode maupun estimasi akuntansi yang digunakan dalam penyusunan laporan keuangan. Salah satu konsep yang dianut dalam proses pelaporan keuangan adalah konsep konservatisme. 
Definisi konservatisme itu sendiri menurut Financial Accounting Standar Board (FASB) adalah reaksi kehati-hatian atas ketidakpastian untuk mencoba memastikan bahwa ketidakpastian tersebut dan risiko yang melekat dapat dipertimbangkan secara memadai. Penggunaan prinsip konservatisme dapat menghasilkan angka-angka laba yang cenderung rendah dan angka-angka beban yang dihasilkan cenderung lebih tinggi. Dengan adanya kebebasan manajemen perusahaan dalam memilih metode akuntansi, beberapa perusahaan justru menjadikan hal tersebut sebagai kesempatan untuk manajemen dalam membuat laporan keuangan dengan prinsip optimisme. Mayangsari dan Wilopo, (2002) dalam Risdiyani, (2015) menyatakan Konservatisme merupakan konsep akuntansi yang kontroversial. Penggunaan konservatisme dapat dianggap bermanfaat yaitu untuk mengurangi risiko dan penggunaan optimisme yang berlebihan yang dilakukan oleh manajer dan pemilik perusahaan, namun di sisi lain penggunaan konservatisme dianggap tidak mencerminkan kondisi keuangan perusahaan yang sebenarnya sehingga dapat mempengaruhi kualitas laporan keuangan perusahaan.

Menurut Watts (2003), konservatisme dapat diukur dengan menggunakan tiga bentuk pengukuran, yaitu 1) Earnings/stock return relation measure, berusaha merefleksikan perubahan nilai aset pada saat terjadinya perubahan, baik perusahaan atas rugi ataupun laba tetap dilaporkan sesuai dengan waktunya. 2) Earnings/accrual measures, instuisi dalam ukuran ini adalah bahwa akuntansi yang konservatif merupakan hasil dari akrual negatif yang persisten (Givoly dan Hyan, 2000). 3). Net asset measures adalah ukuran konservatisme berdasarkan nilai pasar perusahaan yang merupakan nilai rasio market-to-book perusahaan (Baver \& Ryan, 2000).

Setiap perusahaan memiliki alasan dan motif yang kuat dalam menerapkan prinsip konservatisme pada perusahaannya. Salah satu motif dalam pemilihan metode akuntansi yaitu Positif Accounting Theory. Watts dan Zimmerman (1986) berpendapat bahwa terdapat tiga hipotesis dalam teori akuntansi positif (positive accounting theory) yang dapat memotivasi manajer melakukan manajemen laba. Hipotesishipotesis tersebut adalah Hipotesis program bonus (bonus plan hypotesis), hipotesis perjanjian hutang (debt covenant hypotesis), dan hipotesis biaya politik (political cost hypotesis). Dalam penelitian ini peneliti hanya menggunakan hipotesis perjanjian hutang (debt covenant hypotesis) yang diproksikan dengan leverage, dan hipotesis biaya politik (political cost hypotesis) diproksikan dengan size. Selain dari keiga hipotesis yang dijelaskan di atas dalam penelitian ini peneliti menggunakan faktor lain yang dapat mempengaruhi tingkap penerapan konservatisme yaitu good corporate governance yang diproksikan dengan ASEAN Corporate Governance Scorecard, growth opportunities, dan earnings pressure.

Penelitian-penelitian mengenai prinsip konservatisme ini sudah banyak dilakukan namun menghasilkan temuan yang beragam, membuat peneliti merasa bahwa perlu dilakukan pengujian lebih lanjut untuk mengetahui konsistensi temuan jika diterapkan pada kondisi lingkungan yang berbeda. Penelitian ini bertujuan untuk mengetahui pengaruh ASEAN Corporate Governance Scorecard, Leverage, Size, growth Opportunities dan 


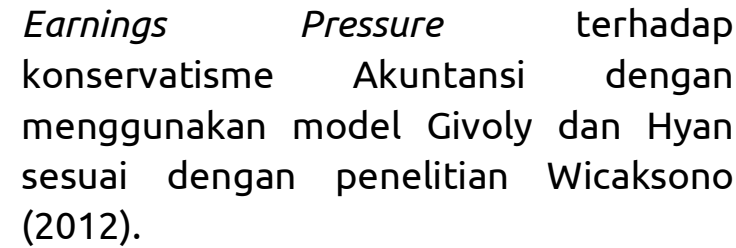

Dalam penelitian ini objek yang digunakan adalah perusahaanperusahaan top rank 50 ASEAN corporate governance scorecard yang dikeluarkan oleh Indonesian Institute for Corporate Directorship (IICD), sebagai Domestic Ranking Body ASEAN corporate governance scorecard. Alasan peneliti menggunakan objek penelitian tersebut karena penilaian yang dilakukan oleh IICD mengenai ASEAN corporate governance scorecard belum dilakukan secara menyeluruh terhadap semua perusahaan yang ada di Indonesia kemudian terdapat variasi industri perusahaan seperti perbankan, kontruksi, pertanian dan pertambangan, manufaktur dan lain-lain.

\section{TINJAUAN LITERATUR DAN PENGEMBANGAN HIPOTESIS}

\section{Teori Keagenan (Agency Theory)}

Teori keagenan menurut Jensen dan Meckling (1976) adalah sebuah kontrak antara principal (pemilik/pemegang saham) dan agent (manajer/pengelola) yang mana baik pemilik dan pengelola sama-sama melakukan pemaksimuman kesejahteraan. Hubungan keagenan merupakan suatu kontrak antara satu atau lebih pihak yang mempekerjakan pihak lain untuk melakukan suatu jasa untuk kepentingan mereka yang meliputi pendelegasian beberapa kekuasaan pengambilan keputusan kepada pihak lain tersebut.
Teori keagenan memiliki asumsi bahwa masing-masing individu sematamata termotivasi oleh kepentingan dirinya sendiri sehingga menimbulkan konflik kepentingan antara prinsipal dengan agen. Pihak prinsipal termotivasi mengadakan kontrak untuk mensejahterakan dirinya dengan profitabilitas yang selalu meningkat sedangkan agen termotivasi untuk memaksimalkan pemenuhan kebutuhan ekonomi dan psikologisnya antara lain dalam hal memperoleh investasi, pinjaman, maupun kontrak kompensasi (Widyaningdyah, 2001).

Uraian di atas menunjukkan bahwa pemilihan penggunaan metode konservatisme oleh perusahaan berkaitan dengan teori ini, karena manajer memilih metode konservatisme tidak terlepas dari keinginan untuk mengoptimalkan kinerjanya dalam perusahaan. Teori keagenan digunakan dalam penelitian ini untuk menjelaskan penerapan konservatisme dalam perusahaan yang dapat dilihat dari laporan keuangan perusahaan yang dapat menyebabkan adanya masalah keagenan antara manajer (agen) dengan stakeholder (prinsipal).

\section{Signaling Theory (Teori Sinyal)}

Signaling theory menjelaskan bahwa pemberian sinyal dilakukan oleh manajer untuk mengurangi asimetri informasi. Manajer memberikan informasi melalui laporan keuangan bahwa mereka menerapkan kebijakan akuntansi konservatisme yang menghasilkan laba yang berkualitas karena prinsip ini mencegah perusahaan melakukan tindakan membesar-besarkan laba dan membantu pengguna laporan keuangan dengan menyajikan laba dan aktiva yang tidak overstate. 
Watts (2003) menyatakan bahwa understatement aktiva bersih yang sistematik atau relatif permanen merupakan salah satu ciri dari konservatisme. Understatement laba dan aktiva bersih yang relatif permanen ditunjukan melalui laporan keuangan merupakan suatu sinyal positif dari manajemen kepada investor bahwa manajemen telah menerapkan akuntansi konservatif untuk menghasilkan laba yang berkualitas. Investor diharapkan dapat menerima sinyal ini dan menilai perusahaan dengan lebih tinggi.

\section{Positive Accounting Theory}

Menurut Chariri dan Ghozali (2007), "teori akuntansi positif (positive accounting theory) menganut paham maksimisasi kemakmuran (wealthmaximisation) dan kepentingan pribadi individu". Jadi teori ini dapat digunakan untuk menjelaskan sifat manajer yang memiliki dorongan untuk memaksimalkan kemakmurannya sendiri. Teori ini juga dapat digunakan untuk memprediksi kinerja buruk manajer yang dapat ditutupi oleh kenaikan laba yang diperoleh perusahaan. Watts dan Zimmerman (1986) berpendapat bahwa terdapat tiga hipotesis dalam teori akuntansi positif (positive accounting theory) yang dapat memotivasi manajer melakukan manajemen laba.

Hipotesis-hipotesis tersebut adalah: "bonus plan hypothesis (hipotesis program bonus), debt covenant hypothesis (hipotesis perjanjian hutang), dan political cost hypothesis (hipotesis biaya politik)." Hubungan antara positive accounting theory dengan penelitian ini adalah hipotesis-hipotesis dalam teori akuntansi positif yang dapat digunakan untuk pemilihan keputusan manajemen untuk menggunakan prinsip konservatisme akuntansi. Hipotesishipotesis tersebut memiliki masingmasing proksi yang digunakan sebagai faktor-faktor yang mempengaruhi pemilihan konservatisme akuntansi serta menjadi variabel independen dalam penelitian ini

\section{Pengaruh ASEAN Corporate Governance Scorecard terhadap Konservatisme Akuntansi}

Konservatisme akuntansi dapat
mempersempit peluang manajer
mengambil keuntungan sendiri dan
keuntungan bagi pihak-pihak lain,
menurunkan permasalahan agensi
berkaitan dengan keputusan investasi manajerial, meningkatkan efisiensi utang dan persetujuan kontrak lainnya, memfasilitasi monitoring kontrak dan menurunkan gugatan biaya (Watts 2003a, b; Ball and Shivakumar 2005). Wardhani (2008) dalam Putri (2016) menyatakan bahwa konservatisme akuntansi dalam perusahaan diterapkan dalam tingkatan yang berbeda. Salah satu faktor yang sangat menentukan tingkatan konservatisme adalah komitmen manajemen dan pihak internal perusahaan dalam memberikan informasi yang transparan, akurat, dan tidak menyesatkan bagi investornya. Hal tersebut merupakan bagian dari implementasi good corporate governance. Implementasi dari corporate governance dilakukan oleh seluruh pihak dalam perusahaan, dengan aktor utamanya adalah dewan komisaris perusahaan yang berwenang untuk menetapkan kebijakan perusahaan dan mengimplementasikan kebijakan tersebut. Salah satu dari kebijakan ini terkait dengan prinsip konservatisme yang digunakan oleh perusahaan dalam melaporkan kondisi keuangannya. Oleh karena itu, karakteristik dari dewan 
komisaris perusahaan akan mempengaruhi tingkatan konservatisme yang akan digunakan perusahaan dalam menyusun laporan keuangannya.

Tata kelola perusahaan (Corporate Governance) berperan penting dalam mengimplementasikan konservatisme akuntansi. Perusahaan dengan corporate governance yang kuat akan menunjukan tingginya penerapan konservatisme akuntansi (Yazida, 2011), begitu pula hal nya dengan perusahaan yang masuk top rank 50 penilaian ACGS (ASEAN Corporate Governance Scorecard) secara otomatis menunjukan nilai corporate governance yang tinggi sehingga dapat diartikan bahwa perusahaan yang masuk top rank 50 penilaian ACGS memiliki tingkat penerapan konservatisme tinggi. Perusahan yang memiliki skor ACGS (ASEAN Corporate Governance Scorecard) yang tinggi mencerminkan tingginya penerapan atau implementasi dari prinsip-prinsip tata kelola perusahaan, karena ACGS (ASEAN Corporate Governance Scorecard) itu sendiri merupakan sebuah kerangka penilaian tatakelola perusahaan terbaru yang dikeluarkan ACMF untuk memeringkat tata kelola perusahaan publik di kawasan ASEAN.

Dalam penelitian yang dilakukan oleh Yazida (2011) menyatakan bahwa corporate governance berpengaruh terhadap konservatisme akuntansi. Kekuatan karateristik dari board of directors sebagai salah satu mekanisme corporate govrnance akan berhubungan secara positif dengan konservatisme akuntansi, hal tersebut dikarenakan konservatisme akuntansi merupakan alat yang sangat berguna bagi board of directors (teutama direksi luar) dalam menjalankan fungsi mereka sebagai pengambil keputusan dan pihak yang memonitor manajmen (Wardhani, 2008 dalam Yazida, 2011). Kemudian dalam penelitian Putra, dkk (2015) menyatakan bahwan mekanisme corporate governance yang di proksikan dengan proporsi komisaris independen, kepemilikan modal manajerial, anggota komite audit, dan jumlah dewan komisaris memiliki pengaruh yang positif terhadap konservatisme akuntansi.

Dari hasil uraian di atas, maka dapat disimpulkan hipotesis pertama dalam penelitian ini adalah:

\section{H1 : ASEAN Corporate Governance Scorecard berpengaruh positif terhadap konservatisme Akuntansi.}

\section{Pengaruh Leverage Terhadap Konservatisme Akuntansi}

Dalam kaitannya dengan kontrak utang, menurut Watts dan Zimmerman (1990) debt covenant merupakan salah satu teori akuntansi positif. Untuk mengidentifikasi debt covenant tersebut dapat menggunakan proksi dari tingkat rasio leverage. Rasio leverage juga dapat menjadi suatu indikasi bagi pemberi pinjaman untuk tingkat keamanan pengembalian dana yang telah diberikan kepada perusahaan. Hal tersebut didasari atas struktur modal yang digambarkan oleh rasio leverage, dengan begitu tingkat risiko tak tertagih suatu utang dapat diketahui.

Semakin besar rasio leverage yang digunakan untuk mengukur debt convenant, semakin besar pula kemungkinan perusahaan akan menggunakan prosedur yang meningkatkan laba yang dilaporkan periode sekarang atau laporan keuangan disajikan cenderung tidak konservatif (Sari dan Adhariani, 2009). Hal tersebut 
disebabkan semakin tinggi debt convenant perusahaan maka semakin semakin dekat perusahaan pada batas yang dipersayaratkan dalam kontrak utang (Watts \& Zimmerman, 1990). Semakin ketat batas yang yang dipersyaratkan dalam kontrak utang maka semakin besar kemungkinan terjadinya pelanggaran kontrak utang, dalam situasi ini majajer cenderung memilih metode akuntansi yang lebih optimis akan mengurangi kemungkinan perusahaan melanggar kontrak utangnya dan menghindari perusahaan dari biaya renegoisasi. Noviantari dan Ni Made Dwi (2015) menemukan besarnya rasio leverage mengindikasikan kondisi perusahaan tidak begitu baik. Sehingga manajer cenderung untuk meningkatkan laba agar kondisi keuangan terlihat lebih baik oleh kreditur.

Dari hasil uraian di atas, maka dapat disimpulkan hipotesis kedua dalam penelitian ini adalah:

\section{$\mathrm{H} 2$ : Leverage berpengaruh negatif terhadap konservatisme akuntansi.}

\section{Pengaruh Ukuran Perusahaan Terhadap Konservatisme}

Ukuran perusahaan merupakan salah satu indikator untuk mengamati besar biaya politis yang harus ditanggung. Ukuran perusahaan dapat diukur dengan melihat total aset yang dimiliki oleh suatu perusahaan. Watts dan Zimmerman (1990) berpendapat bahwa political cost hypothesis dapat memprediksikan bahwa perusahaan besar lebih sensitif terkait dengan biaya politis. Hal ini terkait atas dorongan pemerintah, yang menjadi pembuat kebijakan di negara yang bersangkutan, untuk pemabayaran biaya politis. Maka untuk mengurangi pembayaran biaya politis tersebut perusahaan melakukan pelaporan keuangan secara konservatif. Ini didasari atas pernyataan Jensen dan Meckling (1976) serta Watts dan Zimmerman (1978) yang menyatakan bahwa biaya politis akan meningkat seiring dengan ukuran perusahaan.

Pelaporan secara konservatisme pada laporan keuangan dilakukan karena pemerintah menggunakan informasi akuntansi dalam pengalihan kekayaan perusahaan. Scott (2007) juga menyatakan bahwa jika perusahaan menghadapi biaya politis yang semakin besar, maka manajer semakin cenderung pada pemilihan prosedur akuntansi yang menurunkan nilai laba atau konservatif. Pajak merupakan salah satu biaya politis yang selalu dihadapi perusahaan, oleh karena itu untuk menghindari tingginya pajak, manajemen akan cenderung untuk melaporkan laba yang rendah.

Deviyanti (2012) menyatakan: "perusahaan yang masuk dalam kategori besar memiliki sistem yang lebih kompleks serta profit yang lebih tinggi, hal tersebut membuat perusahaan juga menghadapi risiko yang lebih besar." Selain itu, perusahaan yang besar juga dihadapkan dengan besarnya biaya politis yang tinggi, sehingga perusahaan besar cenderung menggunakan prinsip akuntansi yang dapat mengurangi nilai laporan laba untuk mengurangi besarnya biaya politis. Sama hal nya dengan Noviantari dan Ni Made Dwi (2015) juga menemukan bahwa perusahaan besar akan bersikap pesimis dalam penyajian laporan keuangan dan cenderung berhati-hati dalam penyelenggaraan akuntansinya.

Dari hasil uraian di atas, maka dapat disimpulkan hipotesis ketiga dalam penelitian ini adalah: 
H3 : Ukuran perusahaan berpengaruh positif terhadap konservatisme akuntansi.

\section{Pengaruh Growth Opportunites terhadap Konservatisme Akuntansi}

Growth opportunities adalah
kesempatan perusahaan untuk
melakukan investasi pada hal-hal yang menguntungkan (Utama, 2015). Persaingan bisnis yang semakin tajam dan mengglobal semakin menjadi tantangan yang menuntut perusahaan untuk selalu berkembang dan dinamis (Wulandari dkk, 2014).

Perusahaan dengan growth opportunities yang tinggi akan cenderung membutuhkan dana dalam jumlah yang cukup besar untuk membiayai pertumbuhan tersebut pada masa yang akan datang. Oleh karenanya perusahaan akan mempertahankan earning untuk diinvestasikan kembali pada perusahaan dan pada waktu bersamaan perusahaan diharapkan akan tetap mengandalkan pendanaan melalui utang yang lebih besar. Perusahaan yang akan meningkatkan jumlah investasi atau disebut juga dengan perusahaan growth cenderung akan memilih konservatisme akuntansi karena perhitungaan laba yang lebih rendah dari pada menggunakan akuntansi optimis yang memperhitungkan labanya lebih tinggi (Wulandari dkk, 2014).

Hasil penelitian Wulandari dkk (2014) menyimpulkan bahwa growth opportunities berpengaruh tehadap konservatisme akuntansi sejalan dengan dengan penelitian Utama (2015) yang menyimpulkan bahwa growth opportunities berpengaruh terhadap konservatisme akuntansi, Alfian (2013) menyimpulkan bahwa kesempatan tumbuh berpengaruh positif signifikan terhadap konservatisme akuntansi, sama hal nya dengan penelitan Fatmariani (2013) yang menunjukan bahwa growth opportunities berpengaruh signifikan positif terhadap konservatisme.

Dari hasil uraian di atas, maka dapat disimpulkan hipotesis keempat dalam penelitian ini adalah:

H4 : Growth Opportunities berpengaruh positif terhadap konservatisme akuntansi.

\section{Pengaruh Earnings Pressure terhadap Konservatisme Akuntansi}

Earnings pressure adalah suatu tindakan penurunan akrual yang bersifat menurunkan laba untuk tujuan pajak agar pajak yang dibayarkan mejadi kecil (Yin dan Cheng, 2004). Pada perusahaan yang labanya tidak mencapai target, penurunan laba yang dilakukan untuk tujuan pajak dapat dikurangi oleh earnings pressure guna meningkatkan laba akuntansi. Perusahaan yang memperoleh laba (profit firm), ketika labanya telah mencapai atau bahkan melebihi target, penurunan laba yang dilakukan untuk tujuan pajak dapat dikurangi oleh earnings pressure guna melakukan income smoothing.

Penelitian Raharja dkk (2014) menyatakan bahwa earnings pressure berpengaruh positif terhadap konservatisme akuntansi. Dari hasil uraian di atas maka dapat di simpulkan hipotesis kelima dalam penelitian ini adalah:

H5 : Earnings pressure berpengaruh positif terhadap konservatisme akuntansi. Berdasarkan penjabaran hipotesis di atas maka dapat dibuat kerangka hipotesis sebagai berikut: 


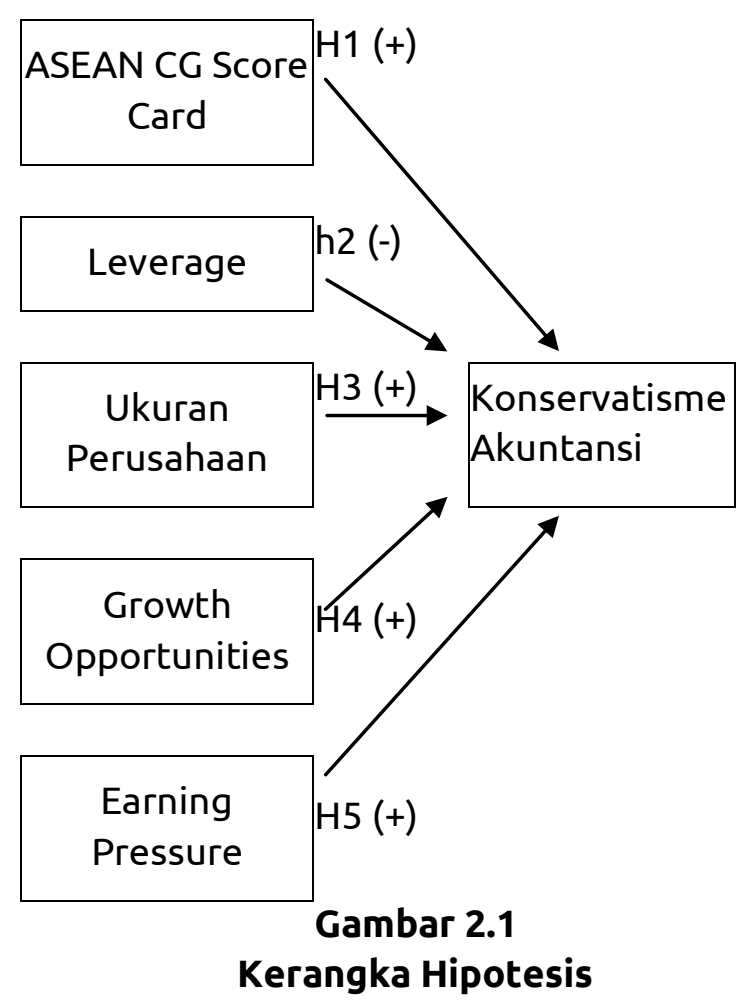

(Sumber : Penulis, 2017)

\section{METODE PENELITIAN}

\section{Jenis, Sumber dan Teknik Pengumpulan Data}

Jenis data yang digunakan dalam penelitian ini adalah data sukunder. Data sukunder yang dimaksud dalam penelitian ini adalah data laporan tahunan perusahaan top rank 50 ASEAN CG Scorecard yang terdaftar di Bursa Efek Indonesia periode 2013-2015. Data yang diperoleh dalam penelitian ini bersumber dari www.idx.co.id. Data dalam penelitian ini adalah data panel yang merupakan gabungan dari data time series dan cross section. Teknik pengumpulan data yang digunakan dalam penelitian adalah studi dokumentasi dan studi kepustakaan.

\section{Populasi dan Sampel}

Populasi yang digunakan pada penelitian ini adalah perusahaan top rank 50 ASEAN Corporate Governance Scorecard berdasarkan penilaian Indonesian of Institute Corporate Directorship (IICD) yang terdaftar di Bursa Efek Indonesia (BEI).

Adapun kriteria yang digunakan dalam penentuan sampel pada penelitian ini adalah sebagai berikut:

1. Perusahaan yang pernah masuk top rank 50 ASEAN Corporate Governance Scorecard berdasarkan penilaian Indonesian Institute for Corporate Directorship (IICD), yang terdaftar dan telah mempublikasikan laporan tahunan Bursa Efek Indonesia (BEI) pada tahun 2013, 2014, dan 2015.

2. Perusahaan tidak mengalami rugi selama periode penelitian.

3. Laporan keuangan dinyatakan dalam satuan mata uang rupiah selama periode penelitian.

4. Perusahaan tidak memiliki ekuitas negatif

5. Memiliki kelengkapan data dalam laporan keuangan yang dibutuhkan untuk proses penelitian.

\section{Varabel Penelitian}

Terdapat lima variabel independen dan satu variabel dependen yang digunakan dalam penelitian ini, adalah sebagai berikut :

\section{Variabel Independen (X)}

Variabel independen dalam penelitian ini adalah ASEAN Corporate Governance Scorecard, leverage, Ukuran 
perusahaan, growth opportunities, dan earnings pressure:

\section{ASEAN Corporate Governance Scorecard}

ASEAN Corporate Governance Scorecard merupakan salah satu kerangka penilaian tata kelola perusahaan terbaru yang diperkenalkan oleh ASEAN Capital Market Forum (ACMF) sebagai suatu alat untuk memeringkat kinerja tata kelola perusahaan publik dan terbuka di ASEAN. Variabel ASEAN Corporate Governance Scorecard diukur dengan menggunakan Variabel Dummy, bernilai 1 jika perusahaan maasuk kedalam top rank 50 ASEAN CG scorecard dan bernilai 0 jika perusahaan tidak masuk kedalam top rank 50 ASEAN CG scorecard

\section{Leverage}

Leverage merupakan rasio yang menunjukkan seberapa besar perusahaan dibiayai dengan utang. Dalam penelitian ini leverage juga akan diukur dengan Debt to Equity Ratio (DER), yaitu suatu perbandingan antara nilai seluruh utang (total debt) dengan nilai seluruh ekuitas (total equity).

Berikut adalah rumus untuk menjelaskan rasio leverage (Irham, 2014):

$$
\text { DER }=\frac{\text { Total Kewajiban }}{\text { Total Ekuitas }}
$$

\section{Ukuran Perusahaan}

Ukuran perusahaan merupakan ukuran atau besarnya aset yang dimiliki oleh perusahaan. Dalam penelitian ini ukuran perusahaan dicerminkan dari logaritma total aset perusahaan, total aset yang semakin besar akan membuat ukuran perusahaan semakin besar. Logaritma natural digunakan karena pada umumnya nilai aset perusahaan sangat besar, sehingga untuk menyeragamkan nilai dengan variabel lainnya nilai aset sampel diubah kedalam bentuk logaritma terlebih dahulu. Perhitungan ukuran perusahaan dengan menggunakan logaritma natural total aset perusahaan sesuai dengan penelitian yang dilakukan oleh Junialika (2016). Berikut ini penjabaran untuk menghitung ukuran perusahaan:

Size $=$ Log Normal Total Aset tahun $_{t}$

\section{Growht opportunities}

Growht opportunities adalah kesempatan perusahaan untuk melakukan investasi dalam hal-hal yang menguntungkan. Penelitian ini memproksikan growth opportunities dengan market to book value equity. Rasio dari market to book value equity menunjukan besarnya perbandingan antara nilai pasar dengan besarnya ekuitas perusahaan.

Berikut ini adalah rumus yang digunakan untuk menjelaskan growth opportunities sesuai dengan penelitian yang dilakukan oleh Utama (2015) :

$$
\text { MBVE }=\frac{\text { Jumla } h \text { saham beredar } X \text { Harga penutupan saham }}{\text { Jumla h ekuitas }}
$$

\section{Earnings Pressure}

Earnings Pressure merupakan salah satu cara yang digunakan untuk menunda atau meningkatan pendapatan dengan cara menggeser pendapatan ke periode yang akan datang.

Berikut ini adalalah rumus yang akan menjelaskan pengukuran earnings pressure sesuai dengan penelitian yang dilakukan Verawaty, (2015): 


$$
E P=\frac{L a b a_{t}-L a b a_{t-1}}{\text { total }_{\text {aset }}{ }_{t}}
$$

\section{Variabel Independen (Y)}

Variabel dependen yang digunakan dalam penelitian ini adalah Konservatisme akuntansi. Menurut Sari dan Adhariani (2009) konservatisme akuntansi adalah konsep yang mengakui biaya dan rugi lebih cepat, mengakui pendapatan dan untung lebih lambat, menilai aktiva dengan nilai terendah dan kewajiban dengan nilai yang tertinggi. Penelitian ini menggunakan pengukuran Earning/accrual measure model Givoly \& Hyan (2000) sesuai dengan penelitian Wicaksono (2012).

Berikut ini adalalah rumus yang akan menjelaskan pengukuran Konservatisme Akuntansi sesuai dengan penelitian Wicaksono (2012):

$$
T A C C_{i t}=\frac{\left(N I_{i t}-C F O_{i t}\right) x-1}{T A_{i t}}
$$

Dimana:

$$
\begin{aligned}
\text { TACCit }= & \text { Total accrual untuk perusahaan } \\
& \text { pada periode } t \\
\text { Niit }= & \text { Net income ditambah dengan } \\
& \text { depresiasi dan amortisasi untuk } \\
& \text { perusahaan } i \text { pada periode } t \\
\text { CFOit }= & \text { Cash flow dari kegiatan operasional } \\
& \text { untuk perusahaan } i \text { pada }
\end{aligned}
$$

\section{Metode Analisis Data}

Penelitian ini menggunakan teknik analisis kuantitatif. Dalam penelitian ini teknik analisis data yang digunakan adalah analisis deskriptif, sebagai alat yang digunakan untuk menggambarkan setiap variabel. Selain itu, penelitian ini menggunakan data panel sehingga model regresi yang digunakan adalah model analisis regresi data panel yang terdiri dari common effect, fixed effect, dan random effect kemudian dari ketiga model regresi data panel tersebut dilakukan pemilihan metode regresi data panel melalui tiga cara yakni yang pertama uji statistik Chow/F digunakan untuk memilih antara common effect atau fixed effect, kedua Langrange Multiplier (LM) Test digunakan untuk memiih antara common effect atau random effect, dan uji yang terakhir adalah hausman test untuk memilih antara fixed effect atau random effect. Setelah terpilih model regresi data panel yang terbaik kemudian dilakukan uji asumsi model regresi data panel yang terdiri dari uji heterokedastisitas, uji autokorelasi, dan uji normalitas dan selanjutnya dilakukan pengujian hipotesis dengan menggunakan analisis regresi linier berganda, perhitungan uji statistik secara parsial (uji signifikansi-t), perhitungan uji statistik secara simultan (uji signifikansi-F) dan uji koefisien determinasi. Alat statistika yang digunakan dalam penelitian ini adalah Microsoft Excel dan program EViews 9.

\section{HASIL DAN PEMBAHASAN}

\section{Analisis Hasil Pengumpulan Data}

Berdasarkan kriteria yang di tentukan dari 69 perusahaan top rank 50 ASEAN corporate Governance Scorecard yang terdaftar di BEI yang memenuhi kualifikasi sebanyak 49 perusahaan. Proses seleksi sampel dapat dilihat dalam tabel 4.1. 
Tabel 4.1

\section{Proses Seleksi Sampel Berdasarkan Kriteria}

\begin{tabular}{|c|l|c|}
\hline No & Kriteria & Jumlah \\
\hline $\begin{array}{l}\text { jumlah Perusahaan yang pernah masuk top rank 50 ASEAN } \\
\text { Corporate Governance Scorecard berdasarkan penilaian } \\
\text { Indonesian Institute for Corporate Directorship (IICD) pada } \\
\text { tahun 2013, 2014 dan 2015 yang terdaftar di BEI. }\end{array}$ & 69 \\
\hline 1 & $\begin{array}{l}\text { Perusahaan yang tidak menyajikan laporan keuangan } \\
\text { secara berturut-turut pada tahun 2013, 2014, dan } \\
2015 .\end{array}$ & $(1)$ \\
\hline 2 & $\begin{array}{l}\text { Perusahaan yang mengalami rugi selama periode } \\
\text { penelitian. }\end{array}$ & $(10)$ \\
\hline 3 & Laporan disajikan tidak dalam satuan mata uang rupiah & $(5)$ \\
\hline 4 & Perusahaan yang memiliki ekuitas negatif & $(3)$ \\
\hline 5 & $\begin{array}{l}\text { Tidak memiliki kelengkapan data dalam laporan } \\
\text { keuangan yang dibutuhkan untuk proses penelitian. }\end{array}$ & $\mathbf{4 9}$ \\
\hline & Perusahaan yang dijadikan sampel & $\mathbf{3}$ (Tahun) \\
\hline & Periode Penelitian & $\mathbf{1 4 7}$ \\
\hline & Total Observasi & \\
\hline & $\begin{array}{l}\text { Catatan : } \\
\text { Perusahaan Manufaktur } \\
\\
\text { Perusahaan Jasa }\end{array}$ & \\
\hline
\end{tabular}

Sumber : data diolah oleh peneliti, (2017)

Tabel 4.2

Statistik Deskriptif

\begin{tabular}{lcccccc}
\hline & KONSERVATISME & ACGS & LEVERAGE & SIZE & GROWTH & EP \\
& & & & & & \\
\hline Mean & -0.015371 & 0.741497 & 3.149840 & 13.63172 & 3.880276 & -0.005572 \\
Median & -0.006900 & 1.000000 & 1.610300 & 13.47610 & 1.919700 & 0.002700 \\
Maximum & 0.154700 & 1.000000 & 13.33220 & 14.95910 & 58.48120 & 0.157300 \\
Minimum & -0.204600 & 0.000000 & 0.001800 & 12.60320 & 0.000900 & -0.871500 \\
Std. Dev. & 0.056070 & 0.439309 & 3.197359 & 0.549040 & 7.853187 & 0.078617 \\
Skewness & -0.828936 & -1.103198 & 1.057615 & 0.652535 & 5.374173 & -9.146317 \\
Kurtosis & 4.726055 & 2.217045 & 3.065600 & 2.593810 & 33.78679 & 101.7262 \\
Jarque-Bera & 35.08283 & 33.57234 & 27.43082 & 11.44272 & 6513.041 & 61749.14 \\
Probability & 0.000000 & 0.000000 & 0.000001 & 0.003275 & 0.000000 & 0.000000 \\
Sum & -2.259500 & 109.0000 & 463.0265 & 2003.862 & 570.4006 & -0.819100 \\
Sum Sq. Dev. & 0.458999 & 28.17687 & 1492.574 & 44.01097 & 9004.191 & 0.902378 \\
Observations & 147 & 147 & 147 & 147 & 147 & 147 \\
\hline
\end{tabular}

Sumber: Output EViews 9, 2017

Tabel 4.3

Frekuensi Variabel Dummy

\begin{tabular}{|l|l|r|r|}
\hline & Kategori & frekuensi & persentase \\
\hline ASEAN Corporate & masuk top rank 50 & 108 & 73 \\
\hline Governance Scorecard & tidak masuk top rank 50 & 39 & 27 \\
\hline
\end{tabular}


Berdasarkan tabel 4.1, dari 49 perusahaan tersebut membentuk data time series, dengan 3 observasi dan data cross section sebanyak 49 perusahaan. Sehingga data panel yang dimiliki sebanyak 147 ( $3 \times 49)$ observasi. Dari 49 perusahaan terdapat 8 perusahaan manufaktur, 36 perusahaan jasa dan 5 perusahaan pertanian dan pertambangan.

\section{Analisis Statistik Deskriptif}

Berdasrkan output Eviews 9 statitik deskriptif meliputi observation, mean, median, maximum, standar deviasi, probablilitas dan Jarque Bera. Statistik deskriptif ditunjukan oleh tabel 4.2.

Tabel deskriptif di atas menjelaskan bahwa jumlah observasi dalam penelitian sebanyak 147, dengan lima variabel indpenden dan satu variabel dependent. Hasil analisis deskriptif variabel konservatisme akuntansi menunjukan bahwa dari 147 observasi nilai konservatisme akuntansi yang terbesar sebesar 0.154700 sedangkan nilai konservatisme akuntansi yang terkecil sebesar 0.204600 Kemudian rata-rata dari konservatisme akuntansi adalah -0.015371, standar deviasi atau sebaran data sebesar 0.056070, Jarque-Bera dari variabel konservatisme akuntansi adalah 35.08283 lebih besar dari 5,99 (df 2 dengan alpha 5\%) atau nilai probabilitas 0.000000 (lebih kecil dari 5\%) maka variabel konservatisme akuntansi memiliki data yang tidak berdistribusi normal.

Selanjutnya yaitu variabel ASEAN Corporate Governance Scorecard merupakan variabel dummy, hasil perhitungan menunjukan bahwa $73 \%$ perusahaan masuk kedalam top rank 50 ASEAN Corporate Governance Scorecard, dan $27 \%$ yang tidak masuk top rank 50 ASEAN Corporate Governance Scorecards, dengan kriteria 0 jika tidak masuk keda- lam top rank 50 ASEAN Corporate Governance Scorecard, dan 1 jika masuk top rank 50 ASEAN Corporate Governance Scorecard.

Variabel selanjutnya adalah leverage hasil perhitungannya menunjukan bahwa rata-rata leverage sebesar 3.149840, maximum sebesar 13.33220 dan untuk minimun sebesar 0.001800 Kemudian untuk standar deviasi atau sebaran data sebesar 3.197359, nilai Jarque-Bera dan probabilitasnya masing-masing 27.43082 lebih besar dari 5.99 (df 2 dengan alpha $5 \%)$ dan 0.000001 lebih kecil dari alfa $5 \%$, itu artinya bahwa variabel ini tidak berdistribusi normal.

Selanjutnya adalah variabel ukuran perusahaan (Size) menunjukan bahwa rata-rata ukuran perusahaan sebesar 13.63172 dan memiliki nila imaximum dan minimun masing-masing 14.95910 dan 12.60320 pada. Kemudian untuk standar deviasi sebesar 0.549040 , nilai Jarque-Bera dan probabilitasnya masingmasing 11.44272 lebih besar dari 5.99 (df 2 dengan alpha 5\%) dan 0.003275 lebih kecil dari alfa $5 \%$, itu artinya bahwa variabel ini tidak berdistribusi normal.

Kemudian variabel selanjutnya adalalah kesempatan tumbuh (growth opportunities) menunjukan hasil bahwa rata-rata kesempatam tumbuh (growth opportunities) adalah sebesar 3.880276 dan memiliki nilai maximum dan minimun masing-masing sebesar 58.48120 dan 0.000900 . Lalu untuk standar deviasi sebesar 7.853187, nilai Jarque-Bera dan probabilitasnya masing-masing 6513.041 lebih besar dari 5.99 (df 2 dengan alpha $5 \%)$ dan 0.000000 lebih kecil dari alfa $5 \%$, itu artinya bahwa variabel ini tidak berdistribusi normal.

Variabel terakhir adalah earnings menunjukan hasil bahwa rata-rata earnings pressure adalah sebesar - 
0.005572 dan memiliki nilai maximum dan minimum masing-masing sebesar 0.157300 dan -0.871500 pada perusahaan. . Kemudian untuk standar deviasi sebesar 0.0788617 nilai Jarque-Bera dan probabilitasnya masing-masing 61749.14 lebih besar dari 5.99 (df 2 dengan alpha $5 \%)$ dan 0.000000 lebih kecil dari alfa $5 \%$, itu artinya bahwa variabel ini tidak berdistribusi normal.

\section{Analisis Regresi Data Panel}

Dalam membuat estimasi data panel, langkah yang pertama dilakukan adalah membuat pemodelan yang terdiri dari Common Effect Model, Fixed Effect Model dan Random Effect Model. Kemudian dilakukan Pemilihan model regresi data panel terbaik dengan menggunakan tiga test yaitu sebagai berikut:

1. Chow Test/F Test

Uji ini dilakukan untuk memilih antara model Common Effect dan Fixed Effect. Ketentuan yang akan digunakan dalam pengambilan kesimpulan $F$ Test dapat dilakukan sebagai berikut:

a. Jika nilai probabilitas $\mathrm{F}<\mathrm{a}$ maka $\mathrm{H}_{0}$ ditolak atau menerima $\mathrm{H}_{1}$ (FEM)

b. Jika nilai probabilitas $\mathrm{F}>$ a maka $\mathrm{H}_{0}$ gagal ditolak (CEM)

Berikut ini adalah hasil pengujian chow test:

\section{Tabel 4.4.}

Chow Test

Redundant Fixed Effects Tests

Equation: Untitled

Test cross-section fixed effects

\begin{tabular}{lccc}
\hline Effects Test & Statistic & d.f. & Prob. \\
\hline $\begin{array}{l}\text { Cross-section F } \\
\text { Cross-section Chi- } \\
\text { square }\end{array}$ & 1.018242 & $(48,93)$ & 0.4608 \\
& 62.085655 & 48 & 0.0832
\end{tabular}

Berdasarkan hasil chow test pada tabel 4.4 di atas, didapatkan probabilitas $F$ sebesar 0.4608 . hasil chow test menunjukkan bahwa probabilitas $\mathrm{F}>5 \%$ sehingga model yang terbaik menurut chow test adalah Common Effect Model (CEM).

\section{Langrage Multiple Test (LM)}

LM test ini dilakukan untuk memilih model terbaik antara model random effect dengan model common effect. Dalam menghitung LM test dapat dilakukan dengan cara mensubstitusikan nilai residual dari random effect model kedalam perhitungan dengan ketentuan sebagai berikut:

a. Jika nilai LM statistik > statistik chisquare maka kita meneolak $\mathrm{H}_{0 .}$ (REM)

b. jika LM statistik < chi-squares maka kita menerima $\mathrm{H}_{0}$. (CEM) Berdasarkan perhitungan Langrage Multiple Test, hasil LM statistik sebesar 0.0326 sedangkan nilai chi-square 11,0705 (a $=5 \% \mathrm{df}=5$ ), maka LM statistik < chisquares sehingga menerima $\mathrm{H}_{0}$ dengan kata lain model yang terbaik berdasarkan LM test adalah common effect model.

\section{Hausman Test}

Hausman test dilakukan untuk menguji model terbaik antara Fixed Effect Model dengan Random Effect Model. Dalam penarikan hasil dilakukan dengan membandingkan nilai Fprobabilitas dengan $a$, jika nilai $F-$ probabilitas a yang ditentukann, maka $\mathrm{H}_{0}$ ditolak, dan sebaliknya jika jika nilai Fprobabilitas > a, maka $\mathrm{H}_{0}$ diterima. Hipotesisnya sebagai berikut:

$\mathrm{H}_{0}=$ Random effect model

$\mathrm{H}_{1}=$ Fixed effect model 
Berikut ini adalah hasil pengujian hausman test menggunakan softwaren EViews 9:

\section{Tabel 4.5. \\ Hausman Test}

Correlated Random Effects - Hausman Test Equation: Untitled

Test cross-section random effects

\begin{tabular}{lccc}
\hline Test Summary & $\begin{array}{c}\text { Chi-Sq. } \\
\text { Statistic }\end{array}$ & Chi-Sq. d.f. Prob. \\
\hline $\begin{array}{l}\text { Cross-section } \\
\text { random }\end{array}$ & 7.232361 & 5 & 0.2039 \\
\hline
\end{tabular}

Sumber: Output EViews 9, 2017

Berdasarkan hasil hausman test pada tabel 4.5. diatas, didapatkan probabilitas $F$ sebesar 0.2039. Hasil hausman test menunjukkan bahwa probabilitas $F$ > 5\% artinya $\mathrm{H}_{0}$ diterima, sehingga model yang terbaik menurut hausman test adalah Random Effect Model.

Setiap uji di atas memiliki model yang terbaik berdasarkan estimasinya, berdasarkan chow test model yang terbaik adalah common effect model, LM test menghasilkan model terbaik yang sama dengan chow test yaitu common effect model, sedangkan menurut hausman test model terbaik adalah random effect model. Berdasarkan ketiga uji tersebut, maka model terbaik adalah common effect . hal ini didasarkan pada dua uji yang memiliki hasil yang sama yaitu chow test dan LM test. Berikut ini adalah tabel common effect model:

Tabel 4.6.

\section{Common Effect Model}

Dependent Variable: KONSERVATISME Method: Panel Least Squares

Date: $04 / 11 / 17$

Time: 01:10
Sample: 20132015

Periods included: 3

Cross-sections included: 49

Total panel (balanced) observations: 147

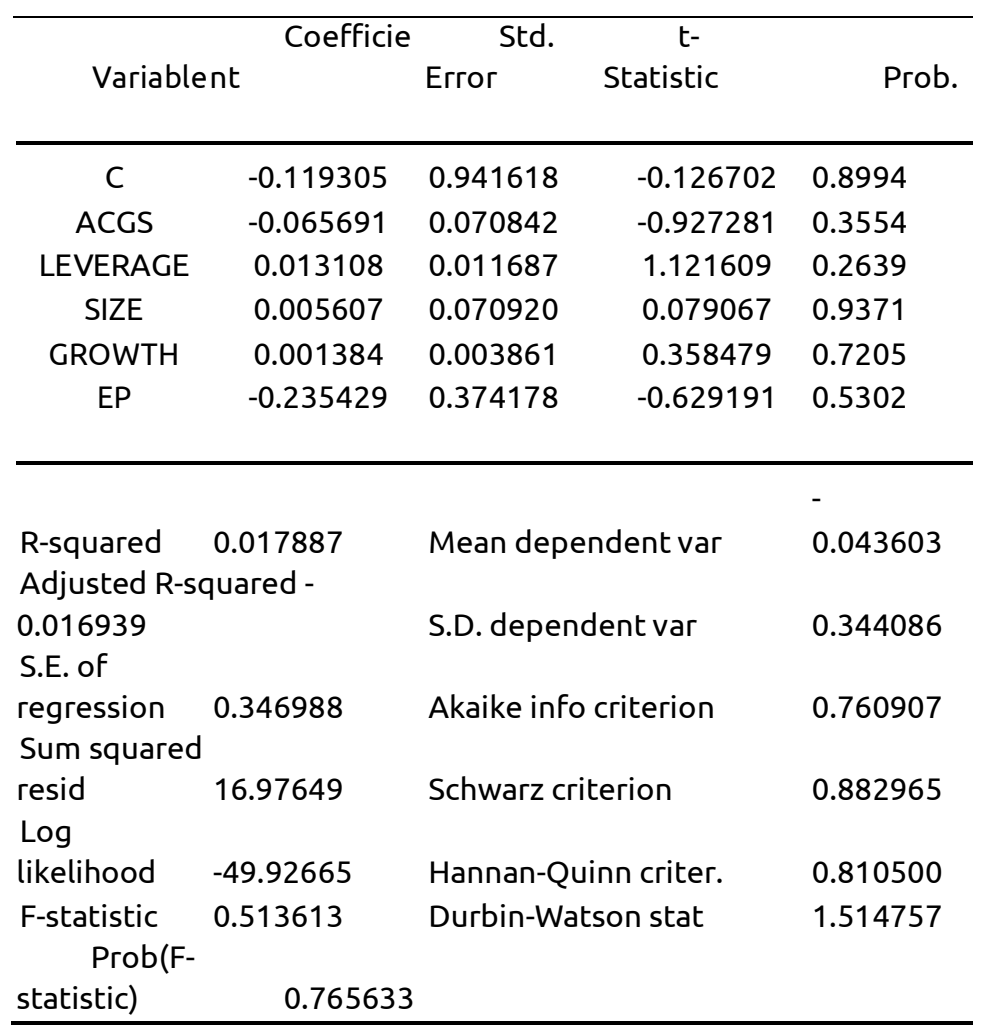

Sumber: Output EViews 9, 2017

\section{Uji Asumsi Model Regresi Data Panel}

Untuk melakukan uji asumsi klasik dalam analisis regresi data panel dapat disesuaikan dengan model yang dihasilkan dari pemilihan model. Ketika model yang terbaik menggunkan pendekatan Ordinary Least Square (OLS) maka uji yang dilakukan hanya uji normalitas, uji heterokedastisitas, dan uji autokorelasi.

Berikut akan dilakukan pengujian asumsi klasik pada model yang telah terpilih yaitu Common Effect Model sebagai berikut:

\section{Uji Normalitas}

Dalam penelitian ini uji normalitas dilakukan dengan dua cara yaitu uji Histogram Residual dan uji Jarque-Bera. 
a. Histrogram residual

Histrogram residual merupakan metode grafis yang paling sedehana digunakan untuk mengetahui apakah bentuk dari probability distribution function (PDF) dari variabel random berbentuk distribusi normal atau tidak. Jika bentuk grafik menyerupai lonceng maka bisa dikatakan bahwa residual mempunyai distribusi normal.

Berikut adalah hasil uji normalitas dengan Histogram Residual menggunakan EViews 9:

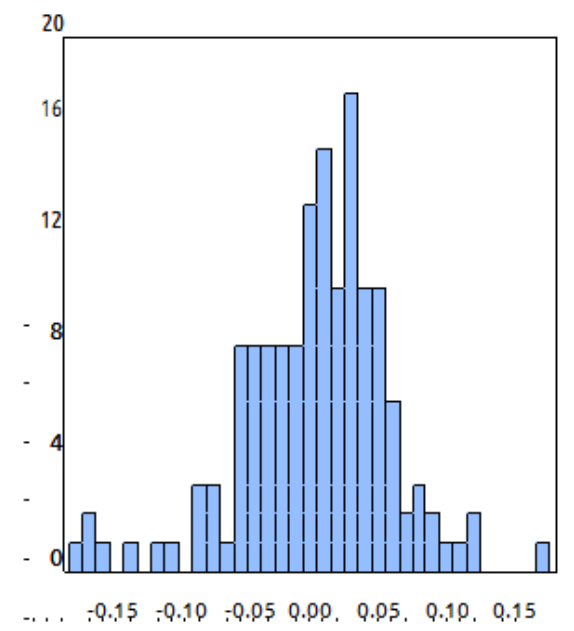

\begin{tabular}{|l|r|}
\hline \multicolumn{2}{|l|}{ Series: Standardized Residuals } \\
\hline Sample & 20132015 \\
\hline Observations & 147 \\
\hline Mean & $-9.99 \mathrm{e}-17$ \\
\hline Median & 0.005346 \\
\hline Maximum & 0.162512 \\
\hline Minimum & -0.170536 \\
\hline Std. Dev. & 0.054049 \\
\hline Skewness & -0.565432 \\
\hline Kurtosis & 4.457183 \\
\hline Jarque-Bera & 20.83869 \\
\hline Probability & 0.000030 \\
\hline
\end{tabular}

Gambar 4.1

Histogram Residual

Sumber : Hasil output Eviews 9

Berdasarkan gambar di atas, dimana grafik histogram menunjukan nilai residual yang tidak berdistribusi normal karena grafik tidak membentuk sebuah lonceng sehingga dapat dikatakan bahwa berdasarkan analisis uji histogram residual model regresi tidak berdistribusi normal. Namun hasil histogram residual belum sepenuhnya dapat di interpretasikan secara tetap untuk mengetahui distribusi data normal dalam sebuah model regresi ini karena menurut Ghozali (2013), bahwa uji normalitas dengan grafik dapat menyesatkan kalau tidak berhati-hati secara visual, padahal secara statistik bisa sebaliknya. Oleh karena itu, selanjutnya akan dilakukan uji normalitas residual dengan menggunakan uji Jarque-Bera.

\section{b. Uji Jarque-Bera}

Uji normalitas Jarque-Bera (JB) adalah sebuah asimtotik atau pengujian dengan sampel besar yang didasarkan pada OLS. Uji ini mengukur perbedaan skewness dan kurtosis dan menggunakan pengujian statistik (Gujiarti dan Porter, 2013). Jika variabel berdistribusi normal maka nilai koefisien skewness $=0$ dan kurtosis $=3$, untuk lebih jelasnya dapat dilakukan dengan melihat nilai JarqueBera dan probabilitasnya. Nilai statistik JB didasarkan pada distribusi normal chisquares dengan derajat kebebasan $(\mathrm{df})=$ 2, artinya jika nilai probabilitasnya lebih besar dari a(disesuaikan $1 \%, 5 \%$, dan $10 \%)$ maka data berdistribusi normal. Sebaliknya, bila probabilitasnya lebih kecil dari a maka data berdistribusi tidak normal.

Berdasarkan gambar 4.1 diketahui nilai skewness dan kurtosis masingmasing sebesar -0.5655432 dan 4.457193. dari nilai skewnwss dan kurtosis maka dapat disimpulkan bahwa variabel tidak berdistribusi normal karena nilai skewness tidak sama dengan nol dan kurtosis tidak sama dengan tiga. Nilai JB sebesar 20.83869 dan 
probabilitas sebesar 0.000030 , sedangkan nilai chi-square dengan df 2 dan a $5 \%$ sebesar 5.99 , sehingga dapat disimpulkan bahwa data tidak berdistribusi normal karena JB statistik> df 2 atau 20.83869> 5.99, sedangkan probabilitas $\mathrm{p}<$ dari $5 \%$ atau $0.000030<$ 0.05. Dapat disimpulkan bahwa uji normalitas berdasarkan uji Jarque-Bera bahwa data residual tidak berdistribusi normal.

Kedua uji normalitas di atas menunjukan bahwa model common effect terdeteksi masalah normalitas dan diperlukan penyembuhan, ketika sebuah model OLS terindikasi masalah uji asumsi klasik maka model regresi bersifat bias atau tidak memenuhi Best Linear Unbiased Estimator (BLUE) dan tidak bisa digunakan untuk mendapatkan estimator yang efisien, sehingga diperlukan penyembuhan. Menurut Gujarati dan Porter (2013) penyembuhan masalah asumsi klasik dapat dilakukan dengan mentrasformasikan model OLS menjadi GLS, melalui GLS weight, sehingga model dapat memenuhi uji asumsi klasik karena model GLS merupakan estimator yang BLUE. Hasil regresi dari tranformasi GLS sebagai berkut:

Tabel 4.7.

\section{Hasil Regresi GLS Weight}

Dependent Variable: KONSERVATISME Method: Panel EGLS (Cross-section weights) Date: 04/11/17 Time: 01:15

Sample: 20132015

Periods included: 3

Sumber: Output EViews 9, 2017

Cross-sections included: 49

Total panel (balanced) observations: 147 Linear estimation after one-step weighting matrix

\begin{tabular}{lllll}
\multicolumn{1}{c}{ C } & -0.242660 & 0.083902 & -2.892186 & 0.0044 \\
\multicolumn{1}{c}{ ACGS } & -0.027184 & 0.009145 & -2.972537 & 0.0035 \\
LEVERAGE & 0.005140 & 0.001462 & 3.516006 & 0.0006 \\
SIZE & 0.015607 & 0.006334 & 2.463980 & 0.0149 \\
GROWTH & 0.001205 & 0.000378 & 3.189759 & 0.0018 \\
EP & -0.112387 & 0.507885 & -1.941551 & 0.5042
\end{tabular}

\begin{tabular}{llll}
\hline \multicolumn{4}{l}{ Weighted Statistics } \\
\hline $\begin{array}{l}\text { R-squared } \\
\text { Adjusted R- }\end{array}$ & 0.278553 & Mean dependent var & 0.134480 \\
$\begin{array}{l}\text { squared } \\
\text { S.E. of }\end{array}$ & 0.252970 & S.D. dependent var & 0.348278 \\
$\begin{array}{l}\text { regression } \\
\text { F-statistic }\end{array}$ & 0.290069 & Sum squared resid & 11.86373 \\
$\begin{array}{l}\text { Prob(F- } \\
\text { statistic) }\end{array}$ & 0.000000 & Durbin-Watson stat & 1.459160 \\
& & &
\end{tabular}

Model di atas merupakan hasil transformasil dari metode OLS ke metode GLS weight dengan model Common Effect Model sehingga menjadi hasil estimasi yang sudah mengalami perbaikan dan dapat memenuhi uji asumsi klasik yang artinya model bersifat BLUE. Dengan demikian, model Common Effect Model dengan metode GLS weight merupakan model yang digunakan dalam penelitian ini untuk menginterpretasikan uji hipotesis dan penarikan kesimpulan. Bersdasarkan tabel di atas, maka model di atas dapat diinterpretasikan dalam persamaan matematika regresi panel sebagai berikut:

\section{TACC $_{\text {it }}=-0.242660-0.027184$ ACGS $_{\text {it }}+$ 0.0051401 LEV $_{\text {it }}+0.015607$ SIZE $_{\text {it }}+$ 0.001205 GROWTH $_{\mathrm{it}}-0.112387 \mathrm{EP}+\varepsilon_{\mathrm{it}}$}

Keterangan:

TACC $_{\text {it }}$ : Total Accrual

ACGS $_{\text {it }}$ : ASEAN Corporate Governance

Scorecard

LEVit : Leverage

SIZEit :Ukuran Perusahaan

\begin{tabular}{cccc}
\hline Variable Coefficient & Std. Error t-Statistic & PGOWOWTHit : Kesempatan pertumbuhan \\
& & Epit \\
\hline & Eit : Earnings Pressure
\end{tabular}


$\beta 0 \quad$ : Konstanta

$\beta 1 \beta 2 \beta 3 \beta 4 \beta 5$ : Koefisien

Berdasarkan regresi linier diatas, dapat diinterpretasikan koefisien regresi dari masing-masing variabel independen sebagai berikut:

1. Konstanta sebesar -0.242660 menyatakan bahwa jika variabel bebasnya yaitu ASEAN Corporate Governance Scorecard $\left(\mathrm{X}_{1}\right)$, Leverage $\left(X_{2}\right)$, Ukuran Perusahaan $\left(X_{3}\right)$, Kesempatan pertumbuhan $\left(\mathrm{X}_{4}\right)$, dan Earnings Pressure $\left(\mathrm{X}_{5}\right)$, konstan atau sama dengan nol maka Konservatisme akuntansi berkurang sebesar -0.242660 .

2. Nilai koefisien regresi variabel ASEAN Corporate Governance Scorecard sebesar -0.027184 , artinya setiap penambahan 1 satuan maka konservatisme akan turun sebesar 0.027184 , dengan asumsi Leverage $\left(\mathrm{X}_{2}\right)$, Ukuran Perusahaan $\left(\mathrm{X}_{3}\right)$, Kesempatan pertumbuhan $\left(\mathrm{X}_{4}\right)$, dan Earnings Pressure $\left(\mathrm{X}_{5}\right)$ konstan.

3. Nilai koefisien regresi variabel Leverage adalah sebesar 0.0051401, artinya setiap penambahan satu satuan Leverage maka konservatisme akuntansi akan naik sebesar 0.0051401, dengan asumsi ASEAN Corporate Governance Scorecard $\left(\mathrm{X}_{1}\right)$, Ukuran Perusahaan $\left(X_{3}\right)$, Kesempatan pertumbuhan $\left(X_{4}\right)$, dan Earnings Pressure $\left(\mathrm{X}_{5}\right)$ konstan.

4. Nilai koefisien regresi variabel Ukuran Perusahaan adalah sebesar 0.015607, artinya setiap penambahan satu satuan Ukuran Perusahaan maka konservatisme akuntansi akan naik sebesar 0.015607, dengan asumsi ASEAN Corporate Governance Scorecard $\left(\mathrm{X}_{1}\right)$, Leverage $\left(\mathrm{X}_{2}\right)$,
Kesempatan pertumbuhan $\left(\mathrm{X}_{4}\right)$, dan Earnings Pressure $\left(\mathrm{X}_{5}\right)$ konstan.

5. Nilai koefisien regresi variabel kesempatan tumbuhadalah sebesar 0.001205 artinya setiap penambahan satu satuan maka konservatisme akuntansi akan naik sebesar 0.001205 dengan asumsi ASEAN Corporate Governance Scorecard $\left(\mathrm{X}_{1}\right)$, Leverage $\left(\mathrm{X}_{2}\right)$, Ukuran Perusahaan $\left(\mathrm{X}_{3}\right)$, dan Earnings Pressure $\left(\mathrm{X}_{5}\right)$ konstan.

6. Nilai koefisien regresi variabel earnings pressure adalah sebesar 0.112387 artinya setiap penambahan satu satuan earnings pressure maka konservatisme akuntansi akan turun sebesar 0.112387 dengan asumsi ASEAN Corporate Governance Scorecard $\left(\mathrm{X}_{1}\right)$, Leverage $\left(\mathrm{X}_{2}\right)$, Ukuran Perusahaan $\left(X_{3}\right)$, dan Kesempatan pertumbuhan $\left(\mathrm{X}_{4}\right)$, konstan.

\section{Pengujian Hipotesis}

\section{Uji Signifikansi Simultan (F-test)}

Secara sederhana $F$ test dilakukan untuk menunjukkan apakah semua variabel independen yang dimasukkan dalam model mempunyai pengaruh secara bersama-sama terhadap variabel dependen. Output uji signifikansi simultan diinterpretasikan dalam tabel 4.7. sebagaimana yang dipaparkan sebelumnya bahwa hipotesis yang diajukan pada uji-F adalah sebagai berikut:

$\mathrm{H}_{0}$ : secara bersama-sama variabel independen tidak berpengaruh terhadap variable dependen.

$\mathrm{H}_{1}$ : secara bersama-sama variabel independen berpengaruh terhadap variabel dependen. 
Tabel 4.8.

Uji Signifikansi Simultan (F-test)

Weighted Statistics

\begin{tabular}{|c|c|c|c|}
\hline F-statistic & 10.88810 & $\begin{array}{c}\text { Durbin- } \\
\text { Watson } \\
\text { stat }\end{array}$ & 1.459160 \\
\hline $\begin{array}{l}\text { Prob(F- } \\
\text { statistic) }\end{array}$ & 0.000000 & & \\
\hline
\end{tabular}

Sumber: Output EViews 9, (2017)

Berdasarkan uji signifikansi simultan diatas diketahui bahwa probabilitas sebesar 0.0000, artinya probabilitas < signifikansi atau $0.0000<0.05$ maka dapat disimpulkan bahwa $\mathrm{H}_{0}$ ditolak. Sehingga variabel independen secara bersama-sama berpengaruh signifikan terhadap variabel dependen. Artinya variabel independen yang terdiri dari ASEAN Corporate Governance Scorecard, leverage, ukuran perusahaan, growth opportunities dan earnings pressure secara bersama-sama (simultan) mempengaruhi variabel dependen yaitu Konservatisme akuntansi.

\section{Koefisien Determinasi $\left(R^{2}\right)$}

Koefisien determinasi $\left(R^{2}\right)$ pada intinya mengukur seberapa jauh kemampuan model dalam menjelaskan variasi variabel dependen yakni Konservatisme akuntansi.

. Tabel 4.9.

Koefisien Determinasi

Weighted Statistics

\begin{tabular}{|c|c|c|c|}
\hline R-squared & 0.278553 & $\begin{array}{c}\text { Mean } \\
\text { dependent } \\
\text { var }\end{array}$ & -0.134480 \\
\hline $\begin{array}{l}\text { Adjusted R- } \\
\text { squared }\end{array}$ & 0.252970 & $\begin{array}{c}\text { S.D. } \\
\text { dependent } \\
\text { var }\end{array}$ & 0.348278 \\
\hline
\end{tabular}

Sumber: Output EViews 9, 2017

Dari output koefisien determinasi diatas, terlihat bahwa nilai Adjusted $\mathrm{R}$ Square adalah sebesar 0.252970 , hal ini $\begin{array}{llr}\text { menunjukkan } & \text { bahwa } & 25.3 \% \\ \text { Konservatisme } & \text { akuntansi } & \text { pada }\end{array}$ perusahaan sampel dipengaruhi oleh variabel ASEAN Corporate Governance Scorecard, leverage, ukuran perusahaan, growth opportunities, dan earnings pressure, sedangkan $74.7 \%$ dipengaruhi oleh variabel lain yang tidak diteliti. Berdasarkan penelitian terdahulu variabel lain yang mempengaruhi konservatisme akuntansi yaitu kepemilikan publik, dan intensitas modal dalam peneitian Junialika (2016), struktur kepemilikan manajerial (Utama, 2015), kepemilikan institusional, dan financial distress (Risdiyani, 2015), tax planning dan earnings bath (Raharja, 2014) dan sebagainya.

\section{Uji Signifikansi Parameter Individual (Uji Statistik t)}

Uji statistik $t$ dilakukan untuk mengetahui seberapa besar pengaruh satu variabel penjelas/independen secara individual dalam menerangkan variasi variabel dependen. Uji signifikansi parsial dilakukan dengan cara membandingkan statistik probabilitas dengan a, jika statistik probabilitas < a maka variabel independen berpengaruh secara signifikan pada variabel dependen, sebaliknya jika statistik probabilitas > a maka variabel independen tidak berpengaruh secara signifikan.

Tabel 4.10.

\section{Uji Signifikansi Parameter Individual (Uji Statistik t)}

Dependent Variable: KONSERVATISME Method: Panel EGLS (Cross-section weights)

Date: 04/11/17

Time: 01:15

Sample: 20132015

Periods included: 3

Cross-sections included: 49

Total panel (balanced) observations: 147 
Linear estimation after one-step weighting matrix

\begin{tabular}{ccccc}
\hline Variable & Coefficient & Std. Error & t-Statistic & Prob. \\
\hline C & -0.242660 & 0.083902 & -2.892186 & 0.0044 \\
ACGS & -0.027184 & 0.009145 & -2.972537 & 0.0035 \\
LEVERAGE & 0.005140 & 0.001462 & 3.516006 & 0.0006 \\
SIZE & 0.015607 & 0.006334 & 2.463980 & 0.0149 \\
GROWTH & 0.001205 & 0.000378 & 3.189759 & 0.0018 \\
EP & -0.112387 & 0.507885 & -1.941551 & 0.5042 \\
& & & & \\
\hline
\end{tabular}

Sumber: Output EViews 9, 2017

Dari tabel diatas maka dapat diinterpretasikan dalam model persamaan matematik analisis regresi data panel dalam penelitian ini sebagai berikut:

TACC $_{\text {it }}=-\mathbf{0 . 2 4 2 6 6 0 - 0 . 0 2 7 1 8 4}$

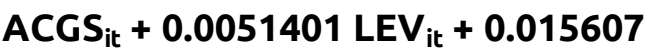

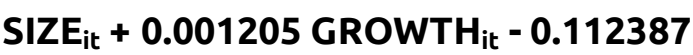
$E P_{i t}+\varepsilon_{i t}$

Berdasarkan uji signifikansi parsial diatas, maka penarikan hipotesis secara parsial dapat disimpulkan sebagai berikut:

1. Hipotesis pertama $\left(H_{1}\right)$ variabel ASEAN Corporate Governance Scorecard berpengaruh negatif terhadap konservatisme akuntansi, yang ditunjukkan dengan nilai probabilitas yang lebih kecilr dari pada a $1 \%(0.0035>0.01)$.

2. Hipotesis kedua $\left(\mathrm{H}_{2}\right)$, variabel leverage berpengaruh positif secara signifikan terhadap konservatisme akuntansi, dengan nilai probabilitas sebesar 0.0006 artinya variabel leverage signifikan pada a $1 \%$ $(0.0006<0.01)$.

3. Hipotesis ketiga $\left(\mathrm{H}_{3}\right)$, variabel ukuran perusahaan berpengaruh positif secara signifikan terhadap konservatisme akuntansi, yang ditunjukkan dengan nilai probabilitas sebesar 0.0149 artinya variabel leverage signifikan pada a 5\% (0.0149 $<0.05$ ).

4. Hipotesis keempat $\left(\mathrm{H}_{4}\right)$, variabel growth opportunities berpengaruh positif secara signifikan terhadap konservatisme akuntansi, yang ditunjukkan dengan nilai probabilitas sebesar 0.0018 artinya variabel growth opportunities signifikan pada a $1 \%(0.0018<0.01)$.

5. Hipotesis kelima $\left.{ }_{(\mathrm{H} 5}\right)_{\text {, }}$ variabel earnings pressure tidak berpengaruh secara signifikan terhadap konservatisme akuntansi, yang ditunjukkan dengan nilai probabilitas lebih besar dari pada a 5\% (0.5042 > 0.05).

\section{PEMBAHASAN}

\section{Pengaruh ASEAN Corporate \\ Governance Scorecard terhadap konservatisme akuntansi.}

Hasil penelitian ini menunjukkan bahwa pengujian untuk hipotesis pertama tidak sesuai dengan hipotesis . Hal ini dapat terlihat dari hasil uji t yang menunjukan nilai koefisien beta 0.027184 dan nilai probabilitas yang lebih kecilr dari pada a 1\% (0.0035> 0.01 Hasil penelitian ini menunjukan bahwa ASEAN Corporate Governance Scorecard (ACGS) berpengaruh negatif terhadap konservatisme akuntansi, sehingga dapat dinyatakan bahwa semakin tinggi skor ACGS akan semakin rendah tingkat konservatisme akuntansi pada sebuah perusahaan

Pengaruh negatif ACGS tersebut diindikasikan karena board of directors pada perusahaan yang dijadikan sampel didominasi oleh pihak internal atau board of directors yang memiliki intensif yang lemah sehingga akan memberikan kesempatan yang lebih besar untuk 
manajer dalam menerapkan tindakan yang menggunakan prinsip akuntansi yang lebih agresif. Selain itu pengaruh negatif tersebut juga diduga ketika perusahaan memiliki skor yang tinggi dalam hal corporate governance dengan masuknya kedalam top rank 50 ASEAN Corporate Governance Scorecard perusahaan telah merasa bahwa dirinya itu baik dan publik memandang perusahaan tersebut dengan positif sehingga perusahaan tersebut tidak lagi mementingkan prinsip konservatif. Dugaan terakhir terkait dengan pengaruh negatif tersebut adalah terkait dengan standar yang digunakan dalam penilaian ASEAN Corporate Governance Scorecard itu sendiri yang menacu pada negara-negara Eropa sementara pada peraktik nya perusahaan-perusahaan di Indonesia secara umum dalam hal operasionalnya menggunakan prinsip Corporate Governance negara Amerika.

Hal tersebut sesuai dengan penelitian Faliyanti (2012) yang menunjukan bahwa mekanisme corporate governance yang diproksikan dengan komisaris independen proporsi, komite audit, kepemilikan saham institusional, dan ukuran dewan komisaris memiliki pengaruh negatif terhadap konservatisme akuntansi, terkecuali dewan komisaris yang memiliki pengaruh positif terhadap konservatisme akuntansi.

\section{Pengaruh Leverage Terhadap Konservatisme Akuntansi}

Hasil penelitian ini menunjukan bahwa pengujian hipotesis kedua $\left(\mathrm{H}_{2}\right)$ tidak sesuai dengan hipotesis. Hal ini dapat terlihat dari hasil uji $t$ yang menunjukan nilai koefisien beta 0.005140 dan nilai probabilitas sebesar 0.0006 artinya variabel leverage signifikan pada a 1\% (0.0006 < 0.01), dengan demikian arah pengaruh yang ditunjukkan pada variabel leverage tidak sesuai dengan $\mathrm{H}_{2}$ yang menyatakan bahwa leverage berpengaruh negatif terhadap konservatisme akuntansi. Dalam penelitian ini leverage berpengaruh signifikan positif terhadap akuntansi.

Pengaruh positif variabel leverage berkaitan dengan semakin tinggi leverage yang dimiliki oleh perusahaan, maka kreditur mempunyai hak lebih besar dalam mengawasi dan mengetahui penyelenggaraan operasi dan akuntansi perusahaan karena kreditur berkepentingan terhadap keamanan dananya yang diharapkan dapat menguntungkan bagi dirinya. Kreditur akan cenderung menuntut manajer untuk menerapkan konservatisme dalam menyusun laporan keuangan. Sehingga рага manajer dituntut untuk melaporkan laporan keuangannya secara konservatif.

Hasil penelitian ini sama dengan penelitian yang dilakukan oleh Dewi dan Suryanawa (2014), dan Alhayati (2013) yang menyimpulkan bahwa leverage berpengaruh signifikan positif terhadap konservatisme akuntansi, Alfian (2013) juga menyimpulkan bahwa leverage berpengaruh signifikan positif terhadap konservatisme akuntansi akuntansi.

\section{Pengaruh Ukuran Perusahaan terhadap Konservatisme Akuntansi}

Hasil penelitian ini menunjukan bahwa hipotesis ketiga $\left(\mathrm{H}_{3}\right)$ diterima dan menolak $\mathrm{H}_{0}$, dengan kata lain variabel ukuran perusahaan memiliki pengaruh yang signifikan positif terhadap konservatisme akuntansi, hal ini dapat terlihat dari hasil uji t yang menunjukan nilai koefisien beta 0.015607 dengan nilai probabilitas sebesar 0.0149 artinya 
variabel leverage signifikan pada a $5 \%$ $(0.0149<0.05)$ dengan demikian $\mathrm{H}_{0}$ ditolak dan $\mathrm{H}_{3}$ diterima.

Hasil penelitian ini sesuai dengan penelitian Noviantari dan Ni Made Dwi (2015), Oktomegah (2012) dan Deviyanti (2012) yang menyimpulkan bahwa ukuran perusahaan berpengaruh signifikan positif terhadap konservatisme akuntansi. Hal ini mengindikasikan bahwa perusahaan besar cenderung menggunakan prinsip akuntansi yang konservatif dalam laporan keuangannya.

Hal ini terkait dengan biaya politis yang harus dilakukan oleh perusahaan tersebut. Hasil ini memberikan indikator bahwa kemungkinan terjadinya transfer kekayaan semakin besar dengan semakin besarnya total aset perusahaan. Hal ini menjadi salah satu pemicu manajer untuk melakukan penurunan laba. Hal ini dikarenakan untuk meminimalkan biaya politis yang mungkin terjadi. Sehingga ukuran perusahaan akan mempengaruhi tingkat biaya politis yang dihadapi perusahaan dan akan mempengaruhi penggunaan prinsip akuntansi yang konservatif (Oktomegah, 2012).

\section{Pengaruh Growth Opportunities Terhadap Konservatisme Akuntansi}

Hasil penelitian ini menunjukan bahwa hipotesis keempat $\left(\mathrm{H}_{4}\right)$ diterima dan menolak $\mathrm{H}_{0}$, dengan kata lain variabel growth opportunities memiliki pengaruh yang signifikan positif terhadap konservatisme akuntansi, hal ini dapat terlihat dari hasil uji $t$ yang menunjukan nilai koefisien beta 0.001205 dengan nilai probabilitas sebesar 0.0014 artinya variabel growth opportunities signifikan pada $1 \%(0.0010$ $<0.01$ ) dengan demikian $\mathrm{H}_{0}$ ditolak dan $\mathrm{H}_{4}$ diterima. Berpengaruhnya growth opportunities dikarenakan perusahaan dengan growth opportunities yang tinggi cenderung akan membutuhkan dana dalam jumlah yang cukup besar untuk membiayai pertumbuhan tersebut pada masa yang akan datang. Perusahaan yang juga akan meningkatkan jumlah investasi atau disebut juga dengan perusahaan growth tersebut cenderung akan memilih konservatisme akuntansi yang perhitungan labanya lebih rendah agar tidak terjadi tindakan-tindakan yang dapat merusak keuangan perusahaan.

Hasil penelitian ini sama dengan penelitian yang dilakukan oleh Fatmariani (2013), dan Alfian (2013) yang menyimpulkan bahwa growth opportunities memiliki pengaruh yang signifikan positif terhadap konservatisme akuntansi.

\section{Pengaruh Earnings Pressure terhadap Konservatisme Akuntasi}

Penelitian ini menunjukkan bahwa hipotesis kelima $\left(\mathrm{H}_{5}\right)$ ditolak dan menerima $\mathrm{H}_{0}$, dengan kata lain variabel earnings pressure tidak memiliki pengaruh terhadap konservatisme akuntansi. Hal ini dapat dilihat dari uji hipotesis dimana tingkat signifikan EP (earnings pressure) menunjukkan nilai 0,5042, dimana nilai tersebut lebih besar dari tingkat signifikansi yaitu 0,05 , dengan demikian penelitian ini menyatakan bahwa earnings pressure tidak berpengaruh terhadap konservatisme akuntansi. Analisis tersebut tidak konsisten dengan hasil penelitian Raharja dkk (2014)y ang menyatakan earnings pressure berpengaruh terhadap konservatisme akuntansi. Akan tetapi, hasil analisis ini konsisten dengan hasil penelitian Wicaksono (2013) dan Verawaty dkk (2015) yang menyatakan bahwa earnings 
pressure tidak berpengaruh terhadap konservatisme akuntansi.

Perusahaan yang labanya tidak mencapai target, penurunan laba yang dilakukan untuk tujuan pajak dapat dikurangi oleh earnings pressure guna meningkatkan laba akuntansi. Perusahaan yang memperoleh laba (profit firm), ketika labanya telah mencapai atau bahkan melebihi target, penurunan laba yang dilakukan untuk tujuan pajak dapat dikurangi oleh earnings pressure guna melakukan income smoothing (Yen dan Cheng, 2004). Namun, penelitian ini tidak mendukung pernyataan tersebut sehingga earnings pressure tidak berpengaruh dalam penerapan konservatisme akuntansi.

Earnings pressure yang tidak berpengaruh terhadap konservatisme akuntansi mengindikasikan bahwa laba diperoleh dari hasil operasi perusahaan, apabila perusahaan mengalami penurunan laba karena operasional perusahaan, tidak akan berdampak pada kebijakan akuntansi yang ditetapkan perusahaan. Hal ini pula menunjukkan bahwa earnings pressure tidak turut dalam mempengaruhi keputusan manajer untuk menurunkan laba jika laba yang diperoleh perusahaan melebihi target untuk tujuan pajak melalui konservatisme akuntansi. Dengan demikian, earnings pressure tidak berpengaruh di dalam penerapan konservatisme akuntansi.

\section{Pengaruh ASEAN Corporate Governance Scorecard, Leverage, Size, Growth Opportinities, Earnings Pressure Terhadap Konservatisme Akuntansi.}

Penelitian ini menunjukan bahwa adanya pengaruh yang signifikan antara ASEAN corporate governance scorecard, leverage, size, growth opportinities, earnings pressure Terhadap Konservatisme Akuntansi pada tingkat signifikansi 5\%. Hal ini dapat terlihat dari hasil statistik uji $\mathrm{F}$ yang menunjukan bahwa nilai signifikansi sebesar 0.0000 $(<0.05)$, dengan demikian dapat disimpulkan bahwa ASEAN corporate governance scorecard, leverage, size, growth opportinities, earnings pressure secara bersama-sama berpengaruh signifikan terhadap Konservatisme Akuntansi.

\section{PENUTUP}

\section{Kesimpulan}

Berdasarkan pembahasan pada bab sebelumnya, maka kesimpulan dalam penelitian ini adalah:

1. ASEAN Corporate Governance Scorecard berpengaruh negatif terhadap konservatisme akuntansi pada perusahaan top rank 50 ASEAN Corporate Governance Scorecard.

2. Leverage berpengaruh positif terhadap konservatisme akuntansi pada perusahaan top rank 50 ASEAN Corporate Governance Scorecard.

3. Size berpengaruh positif terhadap konservatisme akuntansi pada perusahaan top rank 50 ASEAN Corporate Governance Scorecard.

4. Growth opportunities berpengaruh positif terhadap konservatisme akuntansi pada perusahaan top rank 50 ASEAN Corporate Governance Scorecard.

5. Earnings pressure tidak berpengaruh terhadap konservatisme akutansi pada perusahaan top rank 50 ASEAN Corporate Governance Scorecard. 
6. ASEAN corporate governance scorecard, leverage, size, growth opportunities, earnings pressure secara bersama-sama mempengaruhi tingkat konservatisme akuntansi.

\section{Saran}

Berdasarkan hasil penelitian dan kesimpulan di atas, maka saran dalam penelitian ini adalah:

1. Bagi investor sehubungan dengan keputusan dalam menanamkan modal kepada perusahaan disarankan untuk terlebih dahulu melakukan analisa laporan keuangan perusahaan dengan melihat dari penerapan konservatisme akuntansinya (salah satunya bisa dilihat melalui nilai akrual) sebab perusahaan yang menerapkan konservatisme akuntansi cenderung labanya lebih berkualitas karena mencerminkan laba yang nilainya tidak dibesarbesarkan.

2. Bagi perusahaan disarankan untuk lebih berhati-hati dalam memilih metode atau estimasi akuntansi untuk laporan keuangannya sehingga dapat menghindari potensi tuntutan hukum akibat pencatatan laba yang overstatement salah satunya dengan menerapkan konservatisme akuntansi

3. Bagi peneliti selanjutnya diharapkan dapat memelakukan penelitian pada sektor-sektor lain yang ada pada Bursa Efek Indonesia, seperti sektor property dan real estate dan perbankan, untuk mengetahui penerapan konservatisme akuntansi pada sektor-sektor tersebut. Kemudian peneliti selanjutnya diharapkan dapat mempertimbangkan untuk menam- bahkan atau mengganti variabelvariabel terkait dengan good corporate governance agar dapat memperpanjang waktu penelitian. Kemudian untuk peneliti selanjutnya disarankan untuk mengukur konservatisme akuntansi dengan model lain misalnya earning/strock relation measure.

\section{Keterbatasan Penelitian}

Penelitian ini mempunyai keterbatasan-keterbatasan yang dapat dijadikan bahan pertimbangan bagi peneliti selanjutnya agar mendapatkan hasil yang lebih baik lagi. Berikut adalah keterbatasan dalam penelitian ini:

1. Penelitian ini hanya menggunakan lima dari faktor-faktor yang mempengaruhi konservatisme akuntansi, yaitu ASEAN Corporate Governance Scorecard, leverage, size, growth opportunities, earnings pressure.

2. Penelitian ini memiliki keterbatasan data untuk mengetahui skor ASEAN Corporate Governance Scorecard sebagai proksi dari corporate governance sehingga ASEAN Corporate Governance Scorecard hanya di proksikan dengan top rank 50 dan penelitian mengenai ASEAN Corporate Governance Scorecard pun belum dilakukan secara menyeluruh untuk semua perusahaan yang teraftar di Bursa Efek Indonesia. Serta penelitian ini hanya dilakukan selama periode 3 tahun, karena rentang waktu tersebut terbatas maka penelitian ini kurang dapat digeneralisasi. 


\section{DAFTAR PUSTAKA}

Agnes, utari widyaningdyah. 2001. "Analisis Faktor-Faktor Yang Berpengaruh Terhadap Earnings Management Pada Perusahaan Go Public Di Indonesia". Jurnal akuntansi dan keuangan Vol.3.No.2. Universitas Kristen Petra.

Ajija, Schorhrul R dan Setianto, Rahmat H. 2011. "Cara Cerdas Menguasai Eviews". Jakarta. Salemba Empat.

Alfian, Angga dan Arifin Sabeni. 2013. "Analisis Faktor-Faktor Yang Berpengaruh Terhadap Pemilihan Konservatisme Akuntansi" Journal of Accounting Vol. 2. No. 3, Diponegoro.

Aristiyani , D.G. Utami., I Gusti Putu W. 2013. “Pengaruh Debt To Tota Assets, Deviden Pay Out Ratio Dan Ukuran Perusahaan Pada Konservatisme Akuntansi Perusahaan Manufaktur Di BEI". EJurnal Akuntansi Universitas Udayana. Bali

Armein, Rizka Ardhianty. 2005. "Analisis Kasus Laporan Keuangan Pt. Indofarma Tbk. Law Review". Fakultas Hukum Universitas Pelita Harapan. Vol. VI. No. 3

Asia Develpment Bank. 2016. ASEAN Corporate Governance Scorecard Country Report And Assesment 2014. Philppiess

Bahaudin, Ahmad Arif dan Provita Wijayanti. 2011. "Mekanisme Corporate Governance TerhadapKonservatisme Akuntansi Di Indonesia(Studi Empiris Pada Perusahaan Manufaktur Yang Terdaftar Di Bursa Efek Indonesia)". Dinamika Sosial Ekonomi Volume 7 Nomor 1 Edisi Mei 2011. Semarang

Basu, Sudipta. 1997. "The Conservatism Principle And The Asymmetric Timeliness of Earning". Journal of Accounting And Economic 24(1). Hal 151

Beaver, W.H., Ryan, S.G., 2000. "Biases And Lag In Book Value And Their Effect On
The Abilityof The Book Market Ratio To Predic Book Return On Equity". Journal Of Accouning Reseach 38, 127-148.

Brilianti, Dhinny Praswati. 2013. "FaktorFaktor Yang Mempengaruhi Penerapan Konservatisme Akuntansi Perusahaan". Journal AAJ 2(3) (2013). Universitas Negeri Semarang.

Campbell, N. 1938. "Symposium : Measurement And Its Importance For Philosopy. Proceeding of The Aristotelian Society".126

Chariri, Anis Dan Imam Ghozali. 2007. "Teori Akuntansi." Semarang: Badan PenerbitUniversitas Diponegoro.

Deviyanti, Dyahayu Artika. 2012. "Analisis Faktor-Faktor Yang Mempengaruhi Konservatisme Dalam Akuntansi". Skripsi. Universitas Diponegoro.

Dewi, Ni Kd Sri L., I Ketut Suryanawa. 2014. "Pengaruh Struktur Kepemilikan Manajerial, Leverage, Dan Financial Distress Terhadap Konservatisme Akuntansi". E-Jurnal Akuntansi Universitas Udayana 7.1. Bali.

Faliyanti, Putri. 2012. "Pengaruh Struktur Corporate Governance Terhadap

Tingkat Konservatisme Akuntansi Di Indonesia". Universitas Lampung.

Fatmariani. 2013. "Pengaruh Struktur Kepemilikan, Debt Covenant Dan Growth

Opportunities Terhadap Konservatisme Akuntansi Pada Perusahaanmanufaktur Yang Terdaftar Di Bursa Efek Indonesia". Universitas Negeri Padang. Padang.

Financial Accounting Standard Board. 1974. "Financial Accounting Standard No. 2". Norwalk, Connecticut: FSAB

Givoly, D., Hyan, C., 2000. "The Changing Time-Series Properties Og Earnings, Cash Flow And Accrual: Has Financial Reporting Become More Conservative?". Journal Of Accounting And Economics 29, 287-320. 
Gozali, Imam Dan Ratmono Dwi. 2013. "Aplikasi Analisis Multivariat Dan Ekonometrika Teori , Konsep, Dan Aplikasi Dengan Eviws 8". Semarang. Badan Penerbitan Universitas Diponegoro

Gujarti, Damodar N Dan Porter. 2013. "Dasar-Dasar Ekonomika. Buku 1". Jakarta: Salemba Empat.

Gujarti, Damodar N Dan Porter. 2013. "Dasar-Dasar Ekonomika. Buku 2". Jakarta: Salemba Empat.

Ikatan Akuntansi Indonesia. 2015. "Standar Akuntansi Keuangan Per 1 Januari 2015". Jakarta: IAI

Irham Fahmi. 2014. "Analisis laporan keuangan panduan bagi akademis, manajer, dan investor untuk menilai dan menganalisis bisnis dari asek keuangan". Alfabeta. Bandung.

Jensen, M.C. dan W.H. Meckling. 1976. "Theory of the Firm: Manager Behavior, Agency Cost and Ownership Structure". Journal of Finance and Economics.

Julianika, Widia. 2016. "Analisis Pengaruh Struktur Kepemilikan Manajerial, Struktur Kepemilikan Publik, Leverage, Ukuran Perusahaan, Dan Intensitas Modal Terhadap Konsrvatisme Akuntansi (Studi Kasus Pada Perusahaan Manufaktur Yang Terdaftar Di Bursa Efek Indonesi Pada Tahun 2010-2014"). Skipsi. Sekolah Tinggi Ilmu Ekonomi Sutaatmadja. Subang.

Kallapur, S.\& Trombley, M. A. (2001). "The Investment Opportunity Set : Determinants, Consequences and Measurement". Managerial Finance Volume 27 Number 3

Komite Nasional Kebijakann Governanve. 2006. "Pedoman Umum Good Corporate Governance Indonesia". Jakarta

Lafond, Ryan Dan Sugata, Roychowdhury. 2007. "Manageria Ownership And Accounting Conservatism". Www.Ssrn.Com.
Lo, Eko Widodo. 2005. "Pengaruh Tingkat Kesulitan Keuangan Perusahaan Terhadap Konservatisme Akuntansi". Makalah Simposiumnasional Akuntansi Viii. Solo.

Mayangsari.,dan Wilopo. 2002."Konservatisme Akuntansi, Value Relevance And Discretionery Accruals: Implikasi Empiris Model Feltham and Ohlson (1996)". Jurnal Riset Akuntansi Indonesia. Vol. 5

Noviantari, Ni Wayan., Ni Made Dwi. 2015. "Pengaruh Financial Distress, Ukuran Perusahaan, Dan Leverage Pada Konservatisme Akuntansi. E-Jurnal Akuntansi Universitas Udayana 11.3 (2015): 646-660.

Oktomegah, Calvin. 2012. "Analisis FaktorFaktor Yang Mempengaruhi Penerapan Konservatisme Pada Perusahaa Manufaktur Di Bei". Jurnal Mahasiswa Akuntansi - Vol1, No. 1.

Organizational for economic Co-Operation and Development . 2004. OECD principles of corporate governance. Paris. OECD

Otoritas Jasa Keuangan. 2014. Roadmap Tata Kelola Perusahaan Indonesia:Menuju Tata Kelola Emiten Dan Perusahaan Yang Lebih Baik. Jakarta

Peraturan Bank Indonesia. No 8/4.PBI/2006 Tentang Pelaksanaan Good Corporate Governance Bagi Bank Umum.

Peraturan Menteri Badan umum milik negara No. PER-01/MBU/2011 tentang penerapan praktik good corporate governance pada BUMN.

Putra, Wayan. AA.GP.Widanaputra dan Gede Saputra Wijaya. 2015. "Tingkat Konservatisme Akuntansi: Kajian Dewan Komisaris, Modal Manajerial, Dan Komite Audit Dalam Mekanisme Good Corporate Governance". E-Jurnal Akuntansi Universitas Udayana 12.1 (2015): 93-110.

Putri, Irna Yolanda. 2016. "Pengaruh Mekanisme Good Corporate Governance Terhadap Konservatisme Akuntansi 
Pada Perusahaan Manufaktur Di BEI 2012-2014". Artikel Ilmiah. Surabaya.

Raharja, Natalia Dan Sandra Amelia. 2014. "Pengaruh Insentif Pajak Dan Faktor Non Pajak Terhadap Konservatisme Akuntansi Perusahaan Manufaktur Terdaftar Di Bursa Efek Indonesia". Jurnal Prosiding Simposium Nasional Perpajakan.

Rasyidah, Resa. 2013. "Perbandingan Corporate Governance dengan SistemOne-Tier Board di Inggris dan AS Terkait EfektififasPencegahan Terjadinya Fraud dalam Korporasi". Global \& Policy Vol.1, No.1, Januari Juni 2013.

Resti. 2012. "Analisis Faktor-Faktor Yang Mempengaruhi Konservatisme Akuntansi".Skripsi.Universitas Hasanudin.

Risdiyani, Fani. 2015. "Pengaruh Mekanisme Good Corporate Governance, Leverage, Pertumbuhanperusahaan Dan Financial Distress Terhadap Konservatisme Akuntansi (Studi Empiris Pada Perusahaan Manufaktur yang terdaftar di Bursa Efek Indonesi). Skipsi. Universitas Negeri Semarang.

Tricker, Robert Ian, 2009. "Corporate Governance - Principles, Policies and Practices".Oxford: Oxford University Press.

Sari, C, Dan D. Adhariani 2009. "Konservatisme Perusahaan Di Indonesia Dan Faktor-Faktor Yang Mempengaruhinya". Simposium Nasional Akuntansi Xii. Palembang

Sari, Dewi Nadia, Yusralaini Dan Al-Azhar L. 2014. "Pengaruh Struktur Kepemilikan Institusional, Pengaruh Struktur Kepemilikan Publik, Pengaruh Struktur Kepemilikan Manajerial, Debt Convenat Dan Growth Opportunities Terhadap Konsrvatisme Akuntansi". Jom Feekon, Vol. 1 No. 2.

Septian, Ardo Dan Yane Devi Anna. 2014. "Pengaruh Kepemilikan Manajerial, Ukuran Perusahaan, Debt Convenant,
Dan Growth Opportunities Terhadap Konservatisme Akuntansi". Journal Universitas Telkom Bandung.

Smithson, John, 2004. "The Role of the NonExecutive Director in the Small to Medium-Sized Business". New York : Palgrave Macmillan

Sugiono.2015. "Metode Penelitian Dan Pengembangan". Alfabeta. Bandung

Sugiono. 2014. "Metode Penelitian Kombinasi".Alfabeta. Bandung.

Sugiono.2015. "Metode Penelitian Kuantitatif, Kualitatif, Dan R\&D". Alfabeta. Bandung

Sumiari, Kadek Nita dan Dewa Gede. 2016. "Pengaruh Ukuran Perusahaan Terhadap Konservatisme Akuntansi Dengan Leverage Sebagai Variabel Pemoderasi". E-Jurnal Ekonomi dan Bisnis Universitas Udayana 5.4 (2016) : 749-774

Tim Analisis. 2010. "Analisis Pelaksanaan Tata Kelola Emiten Dan Perusahaan Publik". http://www.bapepam.go.id.

Utama, Ikhsan Yoga. 2015. "Pengaruh Struktur Kepemilikan Manajerial, Leverage, Growth Opportunity, Dan Ukuran Perusahaan Terhadap Konservatise Akuntansi (Studi Pada Perusahaan Farmasi Yang Terdaftar Di Bursa Efek Indonesia Pada Tahun 20102014)". Skipsi. Universitas Islam Negeri Syarief Hidayatullah Jakarta. Jakarta.

Verawaty, Citra Indah Meriana, Dan Fitriyani. 2015. "Terhadap Konservatisme Akuntansi Perusahaan Perbankan Di Indonesia". Proceeding Sriwijaya Economic And Busimess Conference.

Watts R. And J.L Zimemerman. 1986. "Posotif Accounting Theory". New York:

Prentice-Hall.

Watts, R. "Conservatism In Accounting Part Ii: Evidence And Research Opportunities". Accounting Horizon 17, 287-301. 2003.

Watts, R. L., Dan erold L., Z. 1990. "Positive Accounting Theory: A Ten Year 
Perspective". The Accounting Riview. Vol. 65, No. 1, Hal. 131-157.

Watts, R.L. 2003. "Conservatism In Accounting Part 1: Explanation And Implication". Journal Of Accounting And Economic. 207-221

Wicaksono, Windra Septian. 2013. "Uji Konservatisme Akuntansi Dalam Diponegoro.

Widarjono, Agus. 2013. "Ekonometrika Yogyakarta. Upp Stim. Ykpn

Empiris Pengaruh Faktor-Faktor Perpajakan". Skripsi. Universita: Pengantar Dan Aplikasinya".

Widya. 2004. "Analisis Faktor-Faktor Yang Mempengaruhi Pilihan PerusahaanTerhadap Akuntansi Konservatif'. Thesis. Pps-UGM.

Wulandari, Indah, Andreas Dan Elfi Ilham. 2014. "Pengaruh Struktur Kepemilikan Manajerial, Debt Convenant Rowth Opportunities Terhadap Konservatisme Akuntansi". JOM FEEKON, Vol. 1 No. 2, Pekanbaru.

Www.Kompas.Co.Id: 2006 (Diakses Pada

Tanggal 13 November 2016)

ww.Tempo.Co.Id: 2009 (Di Akses Pada

Tanggal 13 November 2016)

Yazidah, Izzatul. 2011. "Pengaruh Mekanisme Internal Corporate Governance Terhadap Konservatisme Akuntansi Pada Perusahaan Manufaktur Yang Terdaftar Di Bursa Efeek Indonesi Periode 2004-2009". Skripsi. Universitas Negeri Semarang. 